\title{
Grundtvig og Billeder
}

Bearbejdelse af foredrag holdt på på Skovgaardmuseet 1997

\author{
Af Niels Thomsen
}

Grundtvig brød sig ikke meget om billeder. Heller ikke om skulptur eller arkitektur. Han brød sig i det hele taget ikke meget om kunst. Det er måske et bedrøveligt budskab i en tid, hvor kunsten er i færd med at overtage religionens rolle, og hvor teologer i godt samarbejde med kunstkendere og litterater arbejder p̊̊ at give kristendommen plads blandt muserne. Men det er rigtigt alligevel. Grundtvig dyrkede ikke kunst.

Noget af, hvad han har at sige om kunsten, er velkendt. I 1824 digter han i Jeg kender et land om evighedslandet, hvor aften og morgen går altid i dans med middagens glans, det land som ethvert menneske kender som sin længsel i brystet, det land barnet kender. Den længsel kender kunstneren også. Men vejen til det er lukket:

O flygtige drøm

om evigheds-øen i tidernes strøm, om glædens guldtempel i tårernes dal, om halvgudelivet i dødningesal!

Med dig fra de fleste henfarer på stand de levendes land.

O skuffende drøm!

Du skinnende boble på tidernes strøm!

Forgæves dig skjalden med mund og med pen

af glimrende skygger vil skabe igen.

Når skyggen er ligest, da hulke de små, som stirre derpå.

Fortryllende drøm

om evighedsperlen i tidernes strøm!

Du gækker de arme, som søge omsonst hvad hjertet begærer, i billed og kunst, så varigst de kalde, hvad sikkert forgår som timer og àr.

(DDS 649 str. 3-5) 
I de strofer høres Grundtvigs afregning med forsøget på at skabe og finde evighed i menneskets egen ånd. Det er en afregning med romantikken og det romantiske kunstsyn, troen på at menneskeånden selv kan gribe og fastholde evigheden. Det er ikke en afskrivning af længslen efter evighed. Grundtvig vedkender sig den længsel, men de veje, hans romantiske digterkolleger i samtiden drømte om at gå for at kunne holde evigheden fast $i$ tiden, afskriver han, halvgudelivet med digtere og filosoffer, der fastholder skønheden og kunsten og ånden. Hvor stort det end synes at være, så er det ikke vejen til de levendes land. Det er ikke af evighed, men tværtimod kun en skinnende boble på tidernes strøm. Digteren kender ikke evigheden, men kun en skygge af den. Forgceves dig skjalden med mund og med pen af glimrende skygger vil skabe igen. Lige så lidt griber maler og billedhugger evigheden: Du gakker de arme, som søge omsonst, hvad hjertet begcerer, $i$ billed og kunst, så varigst de kalde, hvad sikkert forgår som timer og år.

Hvad Grundtvig her siger er ikke blot et enkeltstånde poetisk udsagn, men en fast overbevisning. Det fremgår af nogle breve fra $1836 \mathrm{og}$ $1837 \mathrm{i}$ brevvekslingen med Ingemann (Grundtvig og Ingemann. Brevvexling 1821-1859. 1882). Udgangspunktet er Grundtvigs fremhævelse af det levende ord. Ingemann bebrejder ham, at han ikke har sans for åndens virksomhed i skrift og endnu mindre i kunstværker.

Et vigtigt Fænomen i Menneskeslægtens Udviklingshistorie tror jeg dog, du miskjender eller undervurderer; det er den bildende Kunst med Aanden og Livet i dens Værker. De blotte Bogstavers Død maa jeg naturligvis indrømme dig; men naar du hævder det levende Ords Vigtighed og Værd, ser det undertiden ud, som om du ingen Aand og intet Liv erkjendte i Litteraturen ... havde du med mig staaet $i$ Florens og Rom, vilde den Aand og det Liv, den dybe Religjøsitet og Begejstring, der udstrømmer fra den florentinske og romerske Kunstskoles Værker, ogsaa fra Medicæernes Tid, have slaaet dig med Beundring, og du vilde næppe nogen sinde have fordømt slige Mindesmærker om Menneskeaandens højeste Flugt til det historiske Helvede,

og i næste brev:

Øjet og Haanden kunne jo endogsaa gjennem Tider og Slægter være virksommere Organer for Aanden og Livet, end Kjødtungen og 
Bruskøret, saa sandt den aandelige Røst og Hørelse har hjemme i Sjælen og ikke Legemet, hvis Organer tilsammen kun ere Aandens og Livets temporære Tjenere. Alle Rafaelers mundtlige Veltalenhed skulle kun hjulpet os lidet, naar ikke Aanden og Livet hos de Godtfolk havde fundet Udgang gjennem Fingerenderne.

Grundtvig medgiver i sit svar, at ånden, hvor den findes, med stor fornøjelse vedkender sig sine forrige virkninger. Med den kærlighed han har både til Bibelen, der er en virkning af ånd, og hans kærlighed til, hvad skjaldene har efterladt, kan han slet ikke mene andet. Så fortsætter han:

At nu ogsaa Aand lader sig spore i Haandens Kunstvcerker, indrømmer jeg gjærne, selv i højere Grad og videre Udstrækning, end mit Øje er skabt og skikket til at opdage; men ... du lægger langt mere Voegt, end jeg kan billige, paa Aandens Spor i Bygninger, Malerier og Billedstøtter.

Det er ham vigtigt, at gøre forskellen mellem det levende lydelige mundtlige ord på den ene side, og bogstaver og synlige kunstværker på den anden klar. Erfaringen viser, at

en begejstret Røst var aldrig magtesløs, men at alle Kunstværker og selv de såkaldte aandfuldeste Bøger bestandig var det, saa der herskede det største Barbari og den grueligste Aandløshed med de ypperste Kunstværker for Øje og de aandrigeste Bøger mellem Hænderne; ja, Historien viser, at naar Aanden ej mer havde levende Røster til sin Tjeneste, da blev Hyldingen af Kunstværker til Afguderi med det haandgribelige, og Beundringen af de skriftlige Mesterværker det mest aandsfortærende Bogstavvæsen, hvad især Jøders og Grækeres Historie ret forbavsende oplyser.

Grundtvig tydeliggør sin betragtning af forholdet mellem det levende ord og alt det døde, hvad enten det er i skrift eller på lærred eller i sten, ved at understrege forskellen mellem det synlige og det usynlige. Det levende, hørte, lydelige ord er netop usynligt. Det levende ord lever i den spænding, at det er synlige følelige kødlæber og en kødtunge, der frembringer den usynlige verden, hvor ånden virker. 
Hvor megen Aand end Haandens Værker kan forudsætte, besidde de dog ingen, men er kun Tegn og Billeder, som, naar de tages for Aanden selv, forudsætte og nære Aandløshed; mens det ene er Tungen og Læberne givet: i Aandens Tjeneste at frembringe et usynligt Storværk i »det vingede Ord", der sammensmelter med Aanden selv og kan aldrig stjæle, men kun udbrede, befæste og oplyse Aandens Hylding.

Nej, Grundtvig er ikke kunstinteresseret, sådan som det hører til almendannelse at være det nu om stunder, og som menighedsrådene fører det ind i kirken - og salmebogskommissionen i salmebogen. Han synes ganske uforsonlig i sagen trods sit venskab med Ingemann. Ingemann taler, som de kulturelt og åndeligt interesserede gør det nu. Han er betaget af den ånd, der møder ham i den store kunst. Han vil ikke nægte, at ånden også virker i kødtungen og kan formidle ånd til bruskøret, men han ser ingen principiel forskel mellem den ånd, der virker i det levende ord, og den, der møder os i billeder og skulpturer eller i litteraturen.

Det gør Grundtvig; han taler om ånd på en fundamentalt anderledes måde. Hans protest mod at finde ånden i kunstværkerne skyldes ikke, at han er rindalist; han medgiver gerne, at man kan finde åndens spor $\mathrm{i}$ kunstværkerne, og at nogle med rette kan have større sans for det, end han selv har. Men det er netop åndens spor, åndens efterladenskaber, ikke den levende ånd bundet sammen med det levende ord. Hvor man ikke kender den forskel, der nærer man åndløshed i stedet for at leve af ånden. Demonstrationen heraf er selvfølgelig: Barbari og åndløshed blomstrer med de fineste kunstværker for øje; når ånden ikke lever $\mathrm{i}$ talen bliver kunstinteressen til afgudsdyrkelse, og beundringen af den høje litteratur ender i åndsfortærende »bogstavvæsen« (litteraturforskning?).

- Man kunne grunde over, om Grundtvigs forbehold over for kunstværkerne ville have været mindre, hvis han ikke havde mødt en romantisk kunstforståelse som Ingemanns. Hvis han havde mødt en billedforståelse som den, der er udviklet omkring de græske ikoner, hvor billedet er forstået som et vindue ind til den virkelighed, billedet viser hen til. Dermed er man ude over den materialistiske forståelse af ånd, som Grundtvig ser i den åndløse materialistiske kunstdyrkelse. Man kan også spare sig sådanne overvejelser, fordi Grundtvig ikke kendte en sådan billedforståelse, og fordi den moderne kunstforståelse fortsat deler romantikkens og Ingemanns syn. - 
To forhold står klart: At Grundtvig konkret ikke interesserede sig ret meget for den bildende kunst, og at han principielt var på vagt over for det - romantiske - moderne kunstsyn, der fandt ånden i kunsten, fordi han mente, at det førte til åndløshed og afgudsdyrkelse med kunsten.

\section{Grundtvigs billedrigdom}

Og dog har få mennesker skabt billeder som netop Grundtvig. Da jeg stod på en gyngende tovværksbro højt oppe over en vild flod i Nepal, (en bro som den Indiana Jones løber frem og tilbage på i Templets forbandelse), hængt op i tynde flettede tove med nogle trin så møre så man skulle prøve efter med foden hvilke der kunne holde, sprang Grundtvigs billede af den gyngende bro fra $O$, kristelighed frem:

$\mathrm{O}$ vidunder-tro!

du slår over dybet din gyngende bro, som isgangen trodser i brusende strand, fra dødningehjem til de levendes land; bo lavere hos os, det huger dig bedst, du højbårne gæst

(DDS nr. 279 str. 4).

Da jeg var kommet frelst over, kunne jeg også tage meningen bedre til mig, end jeg har gjort før. Der skal megen dristighed til for at forlade sig på en mørnet bro fra bjergside til bjergside over en flod, der bruser med Himalayas smeltevand. Så var der endda ikke isgang, hvad det så ellers er. Den dristighed giver begreb om, hvad en vidundertro er. I den rolige eftertanke fattede jeg siden også, hvor betydningsfuldt det må være at komme fra dødningehjem til de levendes land, når det kan give mod til så dristigt at forlade sig på så skrøbelig en bro.

Sådan går det mig med Grundtvigs billeder. Jeg forstår billederne først; bagefter forstår jeg, hvad de kan bruges til.

Som et lagen det går under alt, hvad består forstod i hvert fald børn fra min generation, før de vidste, hvad det skulle bruges til. Det er svært at forstå meningen med at synge om Gud og tyskerne at Dine fjender til lands er og fjenderne hans, og forstår man meningen, er dens sandhed tvivlsom. Men et barn, der har trukket lagener med sin mor, har let 
ved at forstå, hvor usikker den tilværelse er, under hvilken det går som et lagen.

Hele strofen er en billedprædiken:

Måne og sol

sidde løse på stol;

som et lagen det går

under alt, hvad består;

dog din ven sidder fast i det høje,

over dig våger forsynets øje!

lad kun lovsang afløse din klage!

thi end lever den gamle af dage!

(Hjsk.sangb. 17. udgave nr. 157 str. 3)

Det første billede af solen og månen er apokalyptisk foruroligende. Månen og solen har deres tronstole på himmelhvælvet, og hvad skulle vel sidde mere urokkeligt fast end de store himmellegemer. Når de sidder løst, hvad står så fast?

Inden vi har nået at tænke dén kosmiske usikkerhed til ende, er billedet afløst af det nære tætte, men lige så voldsomme dagliglivsbillede fra rullestuen af lagenet, der går under alt, hvad består.

Så kommer omslaget $\mathrm{i}$ et tredje billede: Din ven sidder fast $i$ det høje. I den usikkerhed, hvor alt, hvad du har forladt dig på, rokkes og vakler eller blafrer som lagenet, kaldes et modbillede frem: Endnu højere end sol og måne, uafhængigt af, at fundamenterne vakler, ser du din ven, der sidder urokket fast. Det billede bindes sammen med et nyt, et emblem, forsynets øje, som vi kender det indskrevet i en trekant, treenighedssymbolet. Over for alverdens uro står den treenige Guds majestætiske forsyn.

Derfor: Vær frimodig og syng lovsang: thi end lever den gamle af dage, han som vi kender fra Daniels bog og Johannes Åbenbaring, han som tager sæde på tronen med klæder hvide som sne og håret som rent uld, den trone, der er som flammende ild. Lad kun sol og måne sidde løse, og lad alt, som består, rystes og kastes omkring. Stol blot på ham og vær tryg! Af billederne springer forståelsen frem og skaber tryghed.

Man skal ikke undre sig over, at Grundtvig undertiden adspurgt heller ikke selv forstod sine billeder, sådan som en anekdote fortæller, at han havde det med v. 4 i Har hånd du lagt på Herrens plov nogle år efter, at den var blevet til: 
Så fremad da i Jesu navn, trods stene og trods stokke!

Og stands ej, om end luefavn

dig byde stolte blokke!

På gløder gå vi allen stund, hvad skin end har den falske grund;

hvi ej engang i lue, hvor alt er klart til skue!

(DDS 575 str. 3)

Billedets klarhed var blevet borte for ham. Jeg genfandt den engang på Etnas skråninger. Salmen begynder:

Har hånd du lagt på Herrens plov, da se dig ej tilbage, se ej til verdens trylleskov

og ej til Sodoms plage!

Billedet af pløjemanden, der for at holde furen lige skal se fremad og ikke bagud, glider sammen med fortællingen om Lots hustru, der ikke måtte vende sig og se tilbage til Sodoma. Billedet af ilden, der regner ned over Sodoma, kalder billedet af et vulkanudbrud frem. Deraf opfordringen til at gå fremad, også om der kastes stenblokke op af luefavnen, ildkrateret. Få tommer under den grå sten, vi går på, er der jo alligevel glødende lava, så på gløder gå vi allen stund, hvordan end overfladen ser ud. Hvor betryggende et udseende den falske grund end har, så kan vi dog hvert øjeblik komme til at stikke benet gennem skorpen ned i ilden. Er det så ikke bedre at gå gennem vulkanens luer, hvor alting, hvor farligt det end er, dog er klart at skue. (Da jeg kom hjem fra Etna, checkede jeg, om ikke der havde været et udbrud af Hekla kort før 1836, da Grundtvig skrev Har hånd du lagt på Herrens plov. Der var ikke fangst).

At Grundtvig har kunnet glemme den forklaring er ikke mærkeligt. Han er seer og ikke pædagog. Det, han vil sige, kalder billeder frem hos ham, men ikke alle billederne kan være lige klare. 
Mange billedkunstnere er seere på samme måde som Grundtvig. Ofte har de endda set næsten de samme billeder. Det slog mig, da jeg i Rom og i Italien så billeder i kirker og katakomber. De billeder, de gamle har efterladt på væggene dér, ligner de billeder, der har meldt sig hos Grundtvig i hans salmer. Grundtvigs salmer ville kunne illustreres rigt med billeder fra kirkens kunstkammer gennem 1800 år. Pointen er bare, at Grundtvig ikke kendte de billeder, så lidt som billedkunstnerne kendte Grundtvig.

\section{Eksempler:}

I en katakombe i Rom (Cimitero Maggiore) er der - oven over et billede af Adam og Eva ved træet i Paradis - et billede af et dødt træ, fra hvis rod en kraftig grøn ranke skyder frem. Billedet er så uanseligt, at man let kunne tage det for ren ornamentik, men når man ser den tværbjælke, der er slået over træstammen, og man bliver opmærksom på sammenhængen med syndefaldsbilledet nedenunder, så melder sig $D u$ som går ud fra den levende Gud med strofe 5:

Livstræet skyde af korsets rod!

Smage lad alle, vor drot er god!

(DDS 248 str. 5)

Det samme billede er vokset videre og er rigt udfoldet i S. Clementes apsismosaik, hvor korset er plantet på Golgatha - som samtidig er Paradisbjerget, hvorfra de fire floder strømmer ud. Fra korsets rod kommer også her et skud, en akantusranke, der fylder hele apsis og giver løvskjul til alverdens liv, kirkeliv og menneskeliv.

I den samme mosaik er der andre billeder, som får en til at huske på Grundtvig. Den hjort, der drikker af Paradisfloden, er næsten for nærliggende til at illustrere salmen Som tørstige hjort monne skrige. Mere horisontudvidende er det at sammenstille billedet på triumfvæggen med Venner, sagde Guds engel blidt. På væggen foran apsismosaikken ses de to byer Jerusalem og Bethlehem. Fårene er samlede foran byernes porte. Hjalmar Torp, den tidligere lektor ved det norske institut i Rom, lærte os, at Jerusalem til højre, ligesom apostlen Peter ovenover, sym- 
boliserer den jødiske menighed, mens Betlehem til venstre står for kirken, vor kirke, kirken af hedninger.

Så melder sig:

Kirke! du er vort Bethlehem, og alle små derinde, efter som det er sagt til dem, skal deres frelser finde med juledags evangelium i hjertekammerets krybberum. (DDS 86 str. 5).

Hjemme kunne jeg så tænke over både, hvad Grundtvig mon havde ment med det, og på hvad de gamle, der skabte det billedprogram, havde ment. Det er ikke sikkert, de mente det samme, men man kan få meget ud af at binde dem sammen. Jeg fik en juleprædiken ud af det.

Man kan blive ved: På den lille ø Torcello i Venedigs lagune ses på vestvæggen i den store kirke den store byzantinske dommedagsmosaik, hvor Kristus sprænger Helvedes porte og Adam og Eva træder frem for Kristus, mens alle Helvedes fanger rejser sig i deres kamre. Det er de billeder, vi er fortrolige med i I Kvceld blev der banket på Helvedes port, hvor Eva tog ordet og gik frelseren nær, og hvor hver fange sig rejste så brat. Grundtvig har hentet dem i de oldengelske kristelige kvad; det gør det ikke mindre forunderligt, at hans digt står i billeder i den flade lagune ved Pos udløb.

Ved at sammenstille Grundtvig salmer med billeder fra den kristne kunsthistorie ville der kunne skabes en prægtig billedbog, hvor poesiens billeder og billedkunstnernes tolkede hinanden.

\section{Hvor Grundtvig har sine billeder fra}

Men før man går i gang med at krydse billeder og salmer på den måde, må man se i øjnene, at Grundtvig vil have set på det med skepsis. Han krydser ikke sindbilleder med oliebilleder. Hvor mange billeder man end bliver mindet om, så henviser han aldrig selv til nogen, end ikke hvor det skulle være mest oplagt: 
Tag det sorte kors fra graven!

Plant en lilje, hvor det stod!

Ved hvert skridt i dødninghaven

blomster spire for vor fod!

Englevinger på vor grav

for den brudte vandringsstav!

Palmefugl for askekrukke!

Frydesang for hule sukke!

(DDS 207 str.1)

kunne, som K.L. Aastrup sagde i sin opposition ved Kaj Thanings disputats være en reklame for en ny stil i gravmonumenter, hvor klassicismens askekrukke og knækkede vandringsstav blev foreslået udskiftet med de mere moderne englevinger og Føniksfugle. Man synes, at Grundtvig må have haft bestemte monumenter for øje, og man er fristet til at gå Københavns gravmonumenter igennem for at finde dem. Det ville gå, som det gik med at efterspore Heklas udbrud.

Det er fordi billederne hos Grundtvig kommer indefra.

Der er to måder at bruge billeder på. Man kan bruge dem bevidst pædagogisk. Når man selv intellektuelt har forstået en sag, kan man bagefter finde pædagogiske billeder, som man kan bruge til at forklare de mindre intellektuelle sagen.

Eller man kan gå ud fra, at sagen selv er i billederne. Når man tager billederne til sig, kommer sagen til klarhed. Forståelsen af sagen vokser frem, mens man tilegner sig billederne. De kan være dunkle, men langsomt klares de; de billeder kan rumme mere, end den, der bruger dem, selv har magt over eller selv har forstået. Et nyt billede udlægger det billede, der gik forud, og den, der bruger billedet, ser selv noget nyt.

Grundtvigs brug af billeder er den sidste. De myldrer frem, tolker hinanden; billede lægger sig til billede. Måske forstår hverken vi læsere eller Grundtvig dem alle sammen. Det gør ingenting, for de griber fat i hinanden. En dag griber man et, og en dag et andet, og en dag forstår man sagen og ser, at man $i$ forvejen har fået foræret de billeder, man skal bruge til at have sagen $i$.

Grundtvig ræsonnerer nogle steder selv over sin billedbrug - bl.a. i en prædiken til 2. Påskedag 1824 - og han har nogle meget dybsindige betragtninger over det hebraiske sprog som ursproget, der af alle sprog lå nærmest ved det sprog Adam og Eva talte i Paradis. Sit eget billedsprog henter han gerne i naturens store billedbog, men fordi menneskets 
syner efter syndefaldet er blevet forvirrede, lader han sin billedbrug vejlede af bibelens billedsprog, der åbenbarer, hvilke lignelser der er brugbare på de himmelske forhold.

Disse udredninger er interessante nok, men jeg er ikke overbevist om, at det er hovedgrunden til at han bruger så mange bibelske billeder. Det er rigtigt, at et utal af hans billeder stammer fra Bibelens billedbrug, er genopglødninger af bibelske billeder. Men mange er det ikke. Det lagen der går under alt, hvad består, stammer ikke fra Mamrelund, men fra rullestuen i Udby.

Der er en anden forklaring, som jeg tror er vigtigere: At Grundtvig tænker i billeder elementært på samme måde som Bibelens forfattere. Derfor mødes hans og deres ånd, og derfor tænder han på billeder af den art.

Sagen selv begynder i billeder. Eksempel: Der er skrevet en del om Grundtvigs forhold til kirkefaderen Irenæus fra det 2. århundrede. Kaj Thaning gjorde et stort arbejde med at gøre Irenæus til grundtvigianer. Men selv siger Grundtvig, at det, der vakte hans kærlighed til Irenæus var et billede, det dejlige jomfrubillede, af jomfru Eva og Jomfru Maria. Hans teologiske tænkning begynder som billedtænkning, og gåderne løses sjældent fuldstændigt.

En af de dybeste kristelige gåder er, hvorledes kristendom fra det døde hebraiske sprog har kunnet opvække levende ord på andre sprog. Han synger om det i Var I ikke galiloeer:

Ja, hvor kan, skønt sproget døde, eders ord på tunger gløde, trodse vid og blok og bål! Hvor kan eders ånd $\mathrm{i}$ Norden, i hver stad og vrå på jorden, tale folkets modersmål!

(DDS 242 str. 3)

Hvordan kan ånden flytte budskabet fra de galilæiske fiskere til Nordens bønder?

Hans teologiske svar er så grundtvigsk korrekt, som det skal være:

Påskemorgen, pinsedagen, ikkun de forklarer sagen, gav jer alle tungers Ånd: 
Ånden, som kan alt udvirke, som i Jesu Kristi kirke løser alle tungebånd. (DDS 242 str. 4)

Det er påskemorgen og pinsedagen, opstandelsen og Helligånden der forklarer det.

Forklaringer, der henviser til den Helligånd, indbyder imidlertid altid til at komme med én forklaring til. Den er at finde i strofe 6, hvor Grundtvig henter et billede fra sin billedkiste frem for nogen, Johannes Åbenbaring:

Sandelig, det var Guds finger, som gav bruden ørnevinger, midt i ørken hus og gård, som gav korsets ord fra Østen sangerstemmen, kæmperøsten her hos os i tusind år.

(DDS 242 str. 6)

Det er billedet af kvinden og dragen i Johannes Åbenbaring kap. 12: Kvinden, bruden, der var klædt i solen og havde månen under sine fødder og 12 stjerner om sit hoved, har født et drengebarn, som dragen vil opsluge. Barnet bliver bortrykket til himlen, men kvinden låner den store ørns vinger til at flyve til det sted, der var beredt for hende i ørkenen, og hvor hun bliver bevaret mens dragen raser indtil dens tid er omme.

Men billedet er oversat til Danmark. Kvinden er kirken, der er blevet borgfrue hos os i Norden og har været det i 1000 år. Hendes flugt på ørnevinger er udtryk for, at lysestagen er flyttet til Højnorden. Her overlever Guds kirke, mens dragen har hærget i Rom og i Tyskland.

Det er en anden måde at forklare kristendommens under på. I strofe 3 var der en dogmatisk forklaring på vers om Helligånden. I strofe 6 er Helligånden og kirken set $\mathrm{i}$ billeder.

Grundtvig ser kristendom i billeder, før han skriver dogmatik. Deri er han fælles med semiterne, hvis vigtigste teologiske værker i de første århundreder var de billedfyldte apokalypser. 


\section{Grundtvig og kunstnerne}

Et spørgsmål står tilbage: Hvor langt Grundtvigs sindbilleder alligevel kan omsættes til oliebilleder eller skulptur og streg. Ét er at Grundtvig ikke var optaget af kunsten, et andet at mange kunstnere har været optaget af Grundtvig og er blevet inspireret af ham. Hvor langt kan de komme med at gengive hans poetiske billeder; og hvor langt kan man komme, uden at man forgriber sig på ånden.

Vi kan nærme os spørgsmålet ved at hente billeder frem fra Den signede dag (DDS 367), Grundtvigs gendigtning af den gamle dagvise til reformationsjubilæet i 1826. Hvor kort eller hvor langt kan billederne kan blive synlige?

Den signede dag med fryd vi ser

af havet til os opkomme;

den lyse på himlen mer og mer,

os alle til lyst og fromme!

Det kendes på os som lysets børn, at natten hun er nu omme!

Det billede kendes fra forsiden af Joakim Skovgaards hefte Den signede dag. Solen går op over havet. Englebørn vågner. En puster lyset ud, som der ikke mere er brug for; en anden flyver ud over strand og hav. Børnene har hvilet i vugger og i senge. Skovgaard synes at høre Velkommen igen Guds engle små med.

Jeg har levet med en anden udgave af det samme billede. Ryslinges lokalkunstner, billedskærer og fløjtespiller Emil Hansen, har brugt det som hovedmotiv på alterrammen i Nazaretkirken i Ryslinge. Hos ham stiger solen op af bølgetoppe og skyer. Over solen flyver lærken i morgenrøde, hentet ind fra strofe 4 , ud over den ny dag.

Thi takke vi Gud, vor Fader god, som lærken i morgenrøde, for dagen, han os oprinde lod, for livet, han gav af døde.

Både Joakim Skovgaards billede og Emil Hansens træskærerarbejde over dette første vers er enkle og ukomplicerede illustrationer. Kun livet, han gav af døde må forblive utolket. 


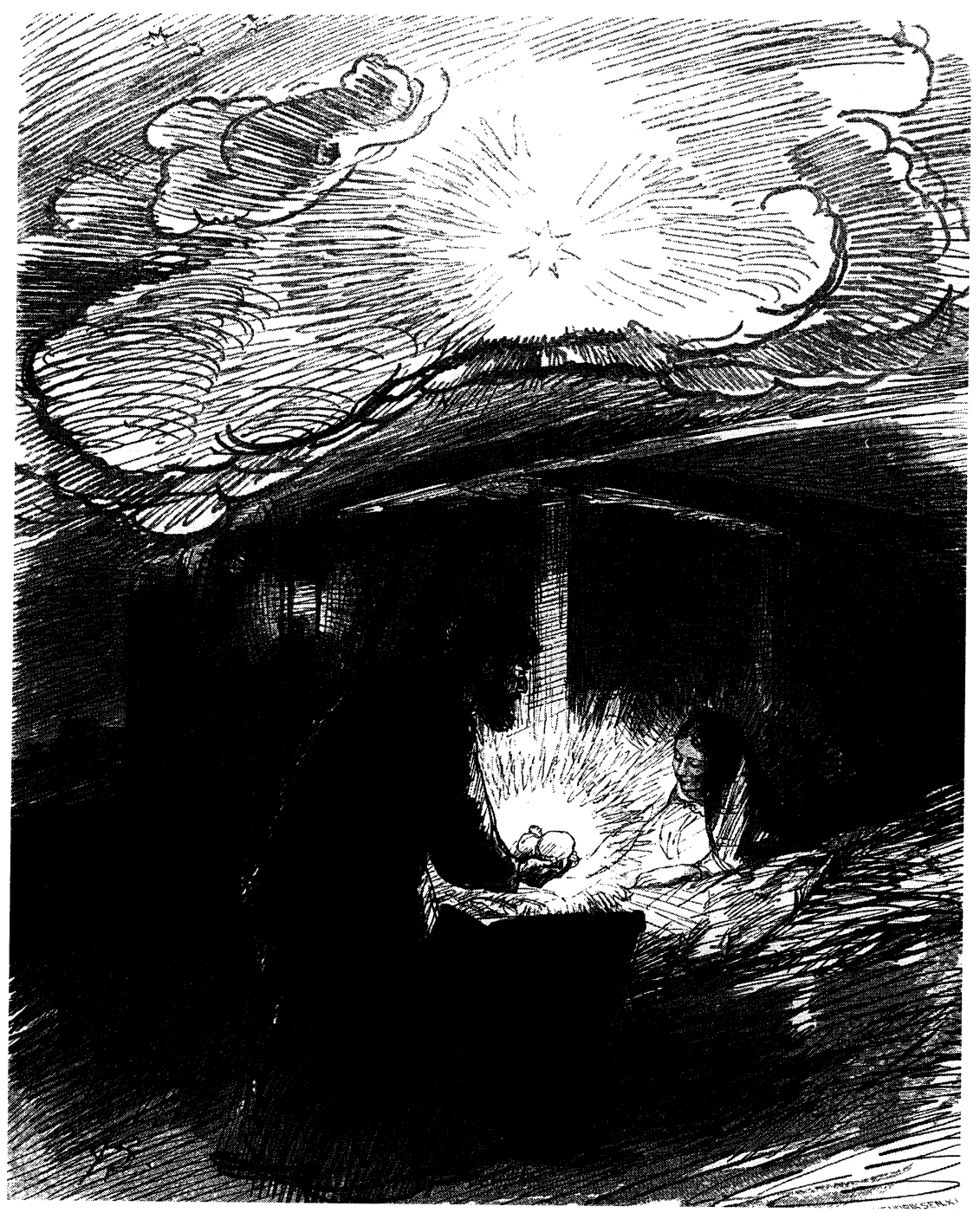

Joakim Skovgaard: Den signede stund.1885.

Skovgaardmuseet, Viborg. 
Anden strofe er det sværere at finde entydige billeder til.

Den signede stund, den midnatstid, vor Herre han lod sig føde, da klared det op i østerlid til dejligste morgenrøde, da lyset oprandt, som jordens bold skal lysne udi og gløde.

Den strofe demonstrerer, hvorfor Grundtvig må have haft det svært med synlige billeder. Han har for mange. Han begynder med et fødselsbillede ved midnatstid med Betlehem og stald. Men deri skal der være et lys. Det har andre prøvet. Correggios Hellige nat har gjort det, men Grundtvig har spændt modsætningen endnu stærkere op. At skabe et lys som ved solopgang samtidig med, at det fastholdes, at det er midnatstid, er ingen let sag, og når jordens bold samtidig skal lysne og gløde i det lys, bliver det svært.

Skovgaard prøver. Stjernen står med stærkt lys. Fødselsrummet ligger hen $i$ et mørke, men midt $i$ er der et andet lys der kommer fra barnet, så Maria oplyses helt og Josef halvt. Stjernens lys og barnets lys spejler hinanden. Det er et godt forsøg, men udtømme Grundtvigs billeder kan det langtfra.

Hjemme har jeg et andet billede til samme strofe. Det er et kakkelbillede af keramiker Bulder Hermansen, lavet som udkast til et nyt alterbillede i Nazaretkirken. Maria står i en dybblå nat, med en glorie af guld, der lyser som solen. Hun står på en jord, der gløder af den sol, der går op bag Maria. Billedet er mindre fortællende og mere kosmisk end Skovgaards.

En tredje udgave er Sven Havsteen-Mikkelsens på Nørgårds Højskole i Bjerringbro. Der er tre billeder. De to sidebilleder, et gyldent og et rødt uden figurativt indhold har hentet idé i strofe 6.

Som guld er den årle morgenstund, når dagen opstår af døde, dog kysser os og med guld i mund den liflige aftenrode.

Midterbilledet er på en gang et julebillede og Den signede dags anden stofe. Det samme motiv er brugt i Todbjerg kirke ved Århus og flere an- 
dre steder. Man skal se det på afstand først. Man ser et stort mørke med et stærkt lys i midten. Går man nærmere, ser man, at det er stalden og at lyset kommer fra barnet i krybben. Således ses på én gang lyset, der skinner i mørket og som mørket ikke får ikke bugt med, og at det lys, der skinner i mørket, er Kristus, der blev født i stalden. Det dækker Grundtvigs kosmiske billede af jorden, der gløder i det lys, der kommer fra den nyfødte Kristus.

Sven Havsteen-Mikkelsen er kommet længst af de tre i retning at indfange de mange sider i Grundtvigs vers. Måske fordi han har lagt sig så tæt på grænsen mellem det figurative og det nonfigurative.

Strofe 2 var svær. Umulig bliver strofe 3:

Om levende blev hvert træ i skov, og var så hvert blad en tunge, de kunne dog ej Guds nådes lov med værdelig røst udsjunge; thi evig nu skinner livets lys for gamle og så for unge.

Der skal males surrealistisk for at få gjort træerne levende, og endnu mere for at få gjort bladene til tunger. Det kunne forsøges; jeg har ikke set det. Men umuligt er det at skildre, at evig nu skinner livets lys. Det er ikke dagens lys. Det er lyset bag lyset, evighedslyset, Jakob Knudsens lysvoeld bag ved lysvceld. Græske ikonmalere har øvet sig i at male det, når de skulle male forklarelsen på bjerget. Jeg har næsten selv set det $\mathrm{i}$ sitrende varme i bjerglandskaber uden for hulekirker i Kappadokien, men fastholdes kan det ikke.

Skovgaard vælger en beskeden løsning, fordi han ved, det ikke kan skildres. Han lader den 12-årige Jesus stå som livets lys og skinne i templet for de gamle mænd, for gamle og så for unge. Sådan spejler han livets lys. Men de andre motiver forbliver utolkede.

Jeg ender her. Skulle jeg gennemgå alle 13 strofer som findes i originalen, ville der blive så mange billeder, at vi ikke kunne holde styr på dem.

Godt det samme ville Grundtvig mene. Hans poetiske billeder kan omsættes til billeder i træ og på lærred og papir, men de ikke kan udtømmes. Hvis synerne kunne udtømmes, hvis sagen selv kunne fastholdes i ét billede, ville faren være der for, at der kunne drives afguderi, fordi det synlige ville binde det usynlige. 
Det synlige bærer det usynlige. Derfor har vi billeder. Uden billeder forstår vi ingenting. Dér bliver kristendom til hjernespind. Men hvor billederne bliver til stof, hvor man tror, at billederne har fastholdt evigheden eller det guddommelige, dér er evighedslængslen tværtimod blot blevet bundet til, hvad sikkert forgår som timer og år.

Grundtvigs smukkeste billeder på forholdet mellem det synlige og det usynlige, ånd og støv, findes i strofe $10 \mathrm{i}$ Jeg kender et land:

O kærligheds Ånd!

Lad barnlig mig kysse din strålende hånd, som rækker fra Himlen til jorderigs muld og rører vort øje med fingre som guld, så blålig sig hæver bag buldrende strand det dejlige land! (DDS 649 str. 10)

Solens strimer ned gennem forårsskoven rører muldet og åbner vort øje. Det er ulegemligt og dog virkeligt. Vi kan forstå det, når vi synger om det. Måske kan det males, så det ligner så meget, at længslen efter evigheden vækkes. Når skyggen er ligest, da hulke de små, som stirre derpå. 